\title{
Fibroblast Growth Factor 23 and Cardiovascular Outcome in Acute Kidney Injury
}

\author{
SIMONA DANIELA ONOFREI ${ }^{1}$, DANIELA RADULESCU ${ }^{1}$, ILEANA PERIDE ${ }^{1 *}$, ANDREI NICULAE ${ }^{1}$, IONEL ALEXANDRU CHECHERITA ${ }^{1}$ \\ ${ }^{1}$ Carol Davila University of Medicine and Pharmacy Bucharest, Faculty of Medicine, Department of Nephrology and Dialysis, St. \\ J ohn Emergency Clinical Hospital, $13^{\text {th }}$ Vitan-Barzesti Road, 042122, Bucharest, Romania \\ ${ }^{2}$ Carol Davila University of Medicine and Pharmacy Bucharest, Faculty of Dental Medicine, Department of Surgery, St. John \\ Emergency Clinical Hospital, 13 $3^{\text {th }}$ Vitan-Barzesti Road, 042122, Bucharest, Romania
}

\begin{abstract}
Even though the identification of Fibroblast Growth Factor 23 (FGF23) has been the breakthrough of the last decades in understanding mineral homeostasis, it is clear that it could have only been the starting point of an outstanding biomarker. This article focuses on available literature data concerning the increase of FGF23 in AKI and its potential influence upon associated or future to be cardiovascular disease.
\end{abstract}

Key words: fibroblast growth factor 23, acute kidney injury, cardiovascular outcome

Fibroblast Growth Factor 23 (FGF23) has so far revolutionized the understanding of chronic kidney diseasemineral and bone disorder (CKD-MBD), but recent researches have surprisingly exposed the potential implications of high levels of circulating FGF23 in the course of acute kidney injury (AKI). Ithas been demonstrated that abnormalities in phosphate and calcium metabolism and increased circulating levels of FGF23 are independent risk factors for cardiovascular diseases, in both healthy and chronic kidney disease (CKD) population. However, a presumed relation of causality between high serum concentrations of this novel phosphatonin in the context of AKI and future risk of cardiovascular diseases remain to be established.

\section{FGF23}

FGF23 was the last member of its family to be discovered and it was revealed to have distinct properties from all the other fibroblast growth factors (FGFs) [1]. While the majority of the FGFs are implicated in various tissues regulating cell proliferation, FGF23 works as a systemic hormone, being itself the master regulator of renal phosphate metabolism and, in consequence, the main element of phosphate homeostasis [1].

Regarding the mechanism of action, the FGF family is divided into three categories: the intracellular, the canonical, and the hormone-like FGFs. FGF23 belongs to the last group because its biological action acquired endocrine characteristics via evolution so that the novel 73 aminoacid $C$ terminus can bind to specific receptors without requiring heparan sulfate proteoglycans as cofactors for local signalling [2]. Instead of using heparin, FGF receptor (FGFR) isoforms require the presence of Klotho (a transmembrane protein produced by osteocytes) as cofactor, therefore the presence of it in various tissues determine the target organ of FGF23 (its specificity) $[1,3]$.

Approximately 251 aminoacids are strung together in the FGF23 structure, making it a rather small molecule weighing about 32-kDa [2-4]. Due to its structure, only the full-length FGF23 protein is biologically active.

Taking into consideration the wide expression of the FGFRs, but the limited presence of the essential coreceptor Klotho, researchers have noted thatFGF 23 exerts its actions mainly in the kidney and less in other targeted organs such as the parathyroid gland, pituitary gland and choroid plexus [4].
FGF23 acts as a lowering serum phosphate hormone. In renal proximal tubular cells, FGF23 binds to FGFR and its coreceptor (Klotho), causing downregulation of the luminal membrane sodium phosphate cotransporter $\mathrm{Na} /$ Pi Ila and, subsequently, reduced phosphate tubular reabsorption [5,6]. Additionally, FGF23 inhibits expression of 1-alpha-hydroxylase in the proximal tubule, therefore decreases vitamin D synthesis [7].

The main FGF23 production site is located in the bone via the contribution of osteocytes. There are also other proposed sources of FGF23, but in unestablished proportions, such as the salivary glands, stomach, skeletal muscle, brain, mammary gland, liver, heart, venous sinuses of the bone marrow, the ventrolateral thalamic nucleus, thymus and lymph nodes [3,4]. Intensive research in molecular biology improved scientists' comprehension on how osteocytes are not actually end-stage inactive cells, revealing that they produce numerous molecules such as FGF23 and osteocalcin, communicating through the lacuna-canalicular network with other bone cells and even distant organs such as the kidney through endocrine mechanisms [8]. Apart from FGF23, osteocytes are an important source of markers and regulators of mineral metabolism, such as sclerostin, phosphate-regulating gene with homologies to endopeptidases on the X chromosome (PHEX), dentin matrix protein-1 (DMP-1) and matrix extracellular phosphoglycoprotein (MEPE), all of which regulate the expression of FGF23. Therefore, circulating levels of phosphate are maintained in order to keep normal bone mineral content. Inadequate circulating levels of FGF23 are the culprit of some disorders due to phosphate imbalance. Elevations of FGF23 are noticed in diseases such as osteomalacia and rickets, inducing excessive phosphorus excretion by the kidney [9]. Increase of FGF23 determines hypophosphatemia and, subsequently, lowers the levels of 1,25-dihydroxyvitamin D, causing rickets/ osteomalacia. In contrast, the opposite results in calcifications of different soft tissues in the body and hyperostosis, such as tumoral calcinosis [4].

\section{FGF 23 in CKD}

$A$ vast amount of data reveals early increase of FGF23 in CKD, even before observing abnormal serum values of parathormon (PTH), phosphate or calcium [10-12]. The main factor stimulating increased production of FGF23 
from bone osteocytes and osteoblasts in early CKD is increased dietary phosphate load [13]; FGF23 accelerates phosphate excretion and, therefore, in early stages of CKD, serum phosphorus is maintained in normal limits [4].

In more advanced CKD stages, increased levels of FGF23 are noted not only as the result of hyperphosphatemia, increased PTH or reduced vitamin D, but also as a result of decreased urinary clearance [14-17]. Nevertheless, there is also evidence that, in advanced stages of CKD, the phosphaturic effect of FGF23 is diminished as a result of decreased expression of Klotho both in the kidney and hyperplastic parathyroid glands [1819]; consequently, hyperphosphatemia is noted.

\section{FGF23 in AKI}

In contrast with CKD, where high levels of FGF23 are considered to be associated with abnormalities in metabolism of calcium, phosphate and PTH, until present, different studies found increased levels of FGF23 in AKI irrespective of alterations in calcium-phosphate axis.

First study revealing abnormal high level of FGF23 in AKI was reported in a patient with rhabdomyolysis-induced acute kidney injury, in 2010 [20]; because AKI induced by rhabdomyolysis is associated with hypocalcemia and hyperphosphatemia, the increase of FGF 23 was considered a compensatory homeostatic response and also the explanation for acute deficiency of 1,25-dihydroxycholecalciferol in these settings. Nevertheless, further studies identified significant high levels of FGF23 in the course of AKI irrespective of serum phosphate levels in critical ill patients, as those admitted in a medical ICU with severe acute tubular necrosis [21] or those developing AKI after cardiac surgery [22]; values were compared with controls without AKI admitted in the same departments and the increase was found significant.

There are proofs from experimental studies that FGF23 increases early in the process of developing AKI [22]; at 1 hour after AKI-induction it was noticed increase of total FGF23, and at 2 hours increase of C-terminal-fragment of FGF23 at ELISA-based analysis. This early elevations suggested the appealing idea of assessing the value of FGF23 level as an early biomarker in AKI. Although there are few studies on FGF23 in AKI, it seems there are promises on this issue. In a study performed by Ali et al on children undergoing cardiac surgery, pre-operative elevated values of C-terminal fragments of FGF23 were associated with higher incidence of post-operative AKI [23]. In the experimental study performed by Cristov etal, the peak of FGF23 increase was noticed at 2 hours after kidney insult in comparison with NGAL (Neutrophil gelatinaseassociated lipocalin), an already confirmed AKI early marker, which registered a peak at 6 hours after AKI induction [22]. In another study on elderly patients it was proven that values of C-terminal FGF 23 above $100 \mathrm{RU} / \mathrm{mL}$ were associated with increased incidence of communityacquired AKI independently of other confounders (albuminuria, cardiovascular disease risk factors, and baseline eGFR -estimated glomerular filtration rate) [24]. The authors reported the incidence of AKI after a median of 10-years follow-up, therefore they emphasized that high levels of FGF23 may announce AKI development over months to years; nevertheless a linear relationship between the magnitude of FGF23 elevation and the risk for AKI development has not been proven.

There is also evidence that, during the course of AKI, there is a direct relationship between the magnitude of $C$ terminal FGF23 elevations and several adverse outcomes as the need for dialysis or death [25]. In addition, in patients with AKI, values of C-terminal FGF23 were found to be much higher in patients with septic shock when compared with values found in patients with uncomplicated sepsis or those found in patients without sepsis [26].

The cause of increasing circulating FGF23 in AKI is still a matter of debate. Elevation of C-terminal fragment FGF23 ELISA-analyzed was found not only in patients with AKI, but also in critical ill patients without AKI in medical or surgical ICU departments [22,25]; increase of FGF23 in medical ICU was significant greater in AKI patients compared with non-AKI patients, but it was also significant greater in patients from ICU when compared with those hospitalized in ordinary hospital medical wards. These reports indicate that the magnitude of FGF23 increasing may be influenced by several other factors than AKI, like inflammation, surgery-associated stress, sepsis etc. [27]. Lesser increase of FGF23 may be also due to short-term renal hypoperfusion or various nephrotoxins that do not lead to clinically-manifest acute kidney failure.

Based on experimental researches, it is assumed that the source of elevated FGF23 in AKI is increased secretion in bone associated with diminished renal clearance [22] independently of PTH and vitamin D metabolism. There are also experimental data showing presence of FGF23 mRNA in renal proximal and distal tubules in animals with diabetes and obesity [28], indicating that bone might not be the only source of increased circulating FGF23. Elevated both bone and ectopic renal secretion of FGF23 has been reported also in alterations of iron metabolism [29-31]; disorders of iron metabolism in AKI have been described in the literature [32] and they were associated with oxidative stress in renal tubules [33], but a cause-effect relationship between these alterations and ectopic secretion of FGF23 in renal tubules has not been confirmed until present.

\section{FGF23 and cardiovascular outcome}

In CKD subjects, increase of FGF23 is associated with greater risk of left ventricular hypertrophy (LVH), independently of other factors like gender, race, type of antihypertensive agents etc. [34]; a direct relationship between FGF23 elevation and risk of major cardiovascular events or cardiovascular mortality was also proven [3538]. The relation between increased FGF23 and cardiovascular outcome was revealed both in advanced CKD (i.e. chronic hemodialysed patients) and also in milder stages [39]; FGF23 levels exceeding the cut-off value of $104 \mathrm{RU} / \mathrm{mL}$ predicted increased risk for cardiovascular events in patients with eGFR rates $>30 \mathrm{~mL} / \mathrm{min} / 1.73 \mathrm{~m}^{2}$ [40].

Significant correlations between FGF23 levels and LVH or low left ventricular ejection fraction (LVEF) were noted also in patients without CKD independently of sex, age, eGFR, serum calcium, phosphate levels or diuretic use [4144]; however, in contrast with CKD, in patients with eGFR $>60 \mathrm{~mL} / \mathrm{min}$ no relationship was noticed between the above mentioned cardiac abnormalities and deficiency of $\alpha$-Klotho [41].In 2014, Scialla and Wolf demonstrated that FGF23 levels are associated with cardiovascular events (especially coronary heart disease) unrelated to phosphate levels, theorizing that the harmful effects of FGF23 and hyperphosphatemia may be separated [45]. Results may be inconsistent so far, considering that Taylor et al found in 2011 that plasma FGF23 levels in the male population without impaired renal function are not associated with coronary heart disease [46]

There is also evidence that in patients withoutCKD there is a direct relationship between the degree of FGF23 
elevation and incidence of cardiac failure [47]. Most studies utilized for analysis circulating levels of FGF23; this might be inappropriate because it is not known if it reflects myocardial FGF23 which can be different in the settings of cardiac failure [41]. One small study performed by Andersen et al concluded that myocardial FGF23 gene expression was present in patients with heart failure at a similar level as normal controls, and immunohistochemistry showed similar cellular distribution of FGF23 in patients with heartfailure and controls, suggesting that the myocardium does not contribute to the elevated circulating FGF23 in heart failure [48].

The mechanisms by which FGF23 induces cardiovascular anomalies are complex and insufficiently known at present.

FGF23 promotes distal tubular reabsorption of sodium in distal tubule with secondary volume overload by increasing the expression of the sodium-chloride cotransporter [49]. It is also implicated in increased distal calcium reabsorption by direct stimulation of epithelial calcium channel which leads to increased vascular resistance and cardiac hypertrophy [34,37,50]. LVH appears to be induced through FGF receptor 4 (FGFR4)-mediated activation of the calcineurin-NFAT signaling pathway $[51,52]$.

In 2013, Six et al experimented in vitro the effects of serum FGF23 and Klotho on human endothelial cells and human vascular smooth muscle cells (VSMC), demonstrating that FGF23 induces vessel contraction and increased ROS (reactive oxygen species) production but sufficient concentrations of Klotho protects vessels from the negative effects of phosphate and FGF23 [53]. Therefore, recent experimental studies on mice tested the potential effects of administering recombinant á-Klotho protein in AKI mice to prevent progression to CKD while lowering FGF23, with promising results [54].

Additionally, FGF23 appears to play an important role in the formation of abnormal tissue calcification (especially arterial calcifications), even though the pathophysiological details are yet to be discovered. For example, formation of hydroxyapatite in VSMC is the result of exposure to high serum phosphate levels in the context of renal failure [55], but FGF23, along with vitamin D metabolites, seems to play a major role in the genesis of vascular and visceral calcifications as demonstrated in experimental mice studies [56]. El-Abbadi etal describes statistical correlation between FGF23 concentrations and aortic calcifications in a study on phosphate-fed uremic mice, raising the suspicion thatFGF23 is directly involved in the development of arterial medial calcifications [57].

Contributing to cardiovascular adverse outcome ratios, there is evidence from community-based studies that FGF23 levels influence the development and severity of atherosclerosis in the context of impaired renal function. However, it is uncertain whether this can be attributed to the atherosclerotic phenomenon itself or vice versa, remaining under debate the implication of FGF23 in plaque formation [58].

Experimental data showed that, at about 5 days after injections of FGF23 into subjects with normal renal, cardiomyocyte hypertrophy and a significant increase in left ventricular wall thickness were noticed; left ventricular hypertrophy was attenuated by administering a FGFR blocker [34]. The LVH FGF23-mediated was FGFR dependent, but independent of Klotho which is not expressed in cardiomyocytes $[59,60]$. The levels of circulating FGF23 obtained by direct injection on animals were comparable with values observed in studies on AKI $[34,61]$. The question if the increase of FGF23 in AKI can induce cardiac hypertrophy during the acute episode or increase future risk of new-onset LVH needs to be answered; therefore, further studies are required to establish if the significance of FGF23 might be changed from a biomarker of cardiovascular risk to a causal factor of the disease and, consequently, FGF23 can be considered a potential target for clinical intervention.

\section{Conclusions}

Identification of FGF23 has been the breakthrough of the last decades in understanding mineral homeostasis and in better defining of CKD-MBD abnormalities, butrecent researches reveal the outstanding possibility that this unique phosphatonin might also be a valuable early marker in acute kidney injury. Moreover, the direct relationship between cardiovascular morbidity and increased FGF23, already proved in CKD, appears to be extended in AKI; human and experimental studies are needed in the future to clarify if the increase of FGF23 is an associated phenomena or one of the causes of the cardiovascular abnormalities noticed in AKI.

\section{References}

1.FUKUMOTO, S., YAMASHITA, T., Bone, 40, nr. 5, 2007, p. 1190

2.ITOH, N., ORNITZ, D.M., Trends Genet., 20, nr. 11, 2004, p. 563

3.MARTIN, A., DAVID, V., QUARLES, L.D., Physiol. Rev., 92, nr. 1, 2012, p. 131

4.LIU, S., QUARLES, L.D., J. Am. Soc. Nephrol., 18, nr. 6, 2007, p. 1637 5.QUARLES, L.D., Exp. Cell Res., 318, nr. 9, 2012, p. 1040

6.MIYAMOTO, K., ITO, M., TATSUMI, S., KUWAHATA, M., SEGAWA, H., Am. J. Nephrol., 27, nr. 5, 2007, p. 503

7.SAITO, H., KUSANO, K., KINOSAKI, M., ITO, H., HIRATA, M., SEGAWA, H., MIYAMOTO, K., FUKUSHIMA, N., J. Biol. Chem., 278, nr. 4, 2003, p. 2206

8.ITO, N., FINDLAY, D.M., ATKINS, G.J ., Clinic Rev. Bone. Miner. Metab., 12, nr. 1, 2014, p. 44

9.BONEWALD, L.F., J. Bone Miner. Res., 26, nr. 2, 2011, p. 229

10.LEVIN, A., BAKRIS, G.L., MOLITCH, M., SMULDERS, M., TIAN, J., WILLIAMS, L.A., ANDRESS, D.L., Kidney Int., 71, nr. 1, 2007, p. 31

11.ISAKOVA, T., WAHL, P., VARGAS, G.S., GUTIÉRREZ, O.M., SCIALLA, J., XIE, H., APPLEBY, D., NESSEL, L., BELLOVICH, K., CHEN, J., HAMM, L., GADEGBEKU, C., HORWITZ, E., TOWNSEND, R.R., ANDERSON, C.A., LASH, J.P., HSU, C.Y., LEONARD, M.B., WOLF, M., Kidney Int., 79, nr. 12, 2011, p. 1370

12.EVENEPOEL, P., MEIJERS, B., VIAENE, L., BAMMENS, B., CLAES, K., KUYPERS, D., VANDERSCHUEREN, D., VANRENTERGHEM, Y., Clin. J. Am. Soc. Nephrol., 5, nr. 7, 2010, p. 1268

13.QUINN, S.J ., THOMSEN, A.R., PANG, J.L., KANTHAM, L., BRAUNEROSBORNE, H., POLLAK, M., GOLTZMAN, D., BROWN, E.M., Am. J. Physiol. Endocrinol. Metab., 304, nr. 3, 2013, p. E310

14.LARSSON, T., NISBETH, U., LJUNGGREN, O., JÜPPNER, H., JONSSON, K.B., Kidney Int., 64, nr. 6, 2003, p. 2272

15.IMANISHI, Y., INABA, M., NAKATSUKA, K., NAGASUE, K., OKUNO, S., YOSHIHARA, A., MIURA, M., MIYAUCHI, A., KOBAYASHI, K., MIKI, T., SHOJI, T., ISHIMURA, E., NISHIZAWA, Y., Kidney Int., 65, nr. 5, 2004, p. 1943

16.MACE, M.L., GRAVESEN, E., HOFMAN-BANG, J., OLGAARD, K., LEWIN, E., Kidney Int., 88, nr. 6, 2015, p. 1304

17.KOMABA, H., GOTO, S., FUJII, H., HAMADA, Y., KOBAYASHI, A., SHIBUYA, K., TOMINAGA, Y., OTSUKI, N., NIBU, K., NAKAGAWA, K., TSUGAWA, N., OKANO, T., KITAZAWA, R., FUKAGAWA, M., KITA, T., Kidney Int., 77, nr. 3, 2010, p. 232

18.CANALEJ 0, R., CANALEJ O, A., MARTINEZ-MORENO, J.M., RODRIGUEZ-ORTIZ, M.E., ESTEPA, J.C., MENDOZA, F.J., MUNOZCASTANEDA, J.R., SHALHOUB, V., ALMADEN, Y., RODRIGUEZ, M., J. Am. Soc. Nephrol., 21, nr. 7, 2010, p. 1125

19.GUTIERREZ, O., ISAKOVA, T., RHEE, E., SHAH, A., HOLMES, J., COLLERONE, G., JUPPNER, H., WOLF, M., J. Am. Soc. Nephrol., 16, nr. 7, 2005, p. 2205 
20.LEAF, D.E., WOLF, M., STERN, L., Nephrol. Dial. Transplant., 25, nr. 4, 2010, p. 1335

21.ZHANG, M., HSU, R., HSU, C.Y., KORDESCH, K., NICASIO, E., CORTEZ, A., MCALPINE, I., BRADY, S., ZHUO, H., KANGELARIS, K.N., STEIN, J., CALFEE, C.S., LIU, K.D., Ann. Intensive Care, 1, nr. 1, 2011, p. 21

22.CHRISTOV, M., WAIKAR, S.S., PEREIRA, R.C., HAVASI, A., LEAF, D.E., GOLTZMAN, D., PAJEVIC, P.D., WOLF, M., JUPPNER, H., Kidney Int., 84, nr. 4, 2013, p. 776

23.ALI, F.N., HASSINGER, A., PRICE, H., LANGMAN, C.B., Pediatr. Nephrol., 28, nr. 6, 2013, p. 959

24.BROWN, J.R., KATZ, R., IX, J.H., DE BOER, I.H., SISCOVICK, D.S., GRAMS, M.E., SHLIPAK, M., SARNAK, M.J., Clin. J. Am. Soc. Nephrol., 9, nr. 2, 2014, p. 239

25.LEAF, D.E., WOLF, M., WAIKAR, S.S., CHASE, H., CHRISTOV, M., CREMERS, S., STERN, L., Clin. J. Am. Soc. Nephrol., 7, nr. 8, 2012, p. 1217

26.LEAF, D.E., WAIKAR, S.S., WOLF, M., CREMERS, S., BHAN, I., STERN,

L., Clin. Endocrinol. (Oxf.), 79, nr. 4, 2013, p. 491

27.NEYRA, J.A., MOE, O.W., HU, M.C., Pediatr. Nephrol., 30, nr. 11, 2014, p. 1909

28.ZANCHI, C., LOCATELLI, M., BENIGNI, A., CORNA, D., TOMASONI, S., ROTTOLI, D., GASPARI, F., REMUZZI, G., ZOJ A, C., PLoS One, 8, nr. 8, 2013, p. e70775

29.WOLF, M., WHITE, K.E., Curr. Opin. Nephrol. Hypertens., 23, nr. 4, 2014, p. 411

30.IMEL, E.A., GRAY, A.K., PADGETT, L.R., ECONS, M.J., Bone, 60, 2014, p. 87

31.SCHOUTEN, B.J ., HUNT, P. ., LIVESEY, J .H., FRAMPTON, C.M., SOULE, S.G., J. Clin. Endocrinol. Metab., 94, nr. 7, 2009, p. 2332

32.DAVIS, C.L., KAUSZ, A.T., ZAGER, R.A., KHARASCH, E.D., COCHRAN, R.P., J. Am. Soc. Nephrol., 10, nr. 11, 1999, p. 2396

33.MARTINES, A.M., MASEREEUW, R., TJ ALSMA, H., HOENDEROP, J.G., WETZELS, J.F., SWINKELS, D.W., Nat. Rev. Nephrol., 9, nr. 7, 2013, p. 385

34.FAUL, C., AMARAL, A.P., OSKOUEI, B., HU, M.C., SLOAN, A., ISAKOVA, T., GUTIÉRREZ, O.M., AGUILLON-PRADA, R., LINCOLN, J., HARE, J.M., MUNDEL, P., MORALES, A., SCIALLA, J., FISCHER, M., SOLIMAN, E.Z., CHEN, J., GO, A.S., ROSAS, S.E., NESSEL, L., TOW NSEND, R.R., FELDMAN, H.I., ST JOHN SUTTON, M., OJO, A., GADEGBEKU, C., DI MARCO, G.S., REUTER, S., KENTRUP, D., TIEMANN, K., BRAND, M., HILL, J.A., MOE, O.W., KURO-O, M., KUSEK, J.W., KEANE, M.G., WOLF, M., J. Clin. Invest., 121, nr. 11, 2011, p. 4393 35.GUTIÉRREZ, O.M., MANNSTADT, M., ISAKOVA, T., RAUH-HAIN, J .A., TAMEZ, H., SHAH, A., SMITH, K., LEE, H., THADHANI, R., JUPPNER, H., WOLF, M., N. Engl. J. Med., 359, nr. 6, 2008, p. 584

36.J EAN, G., TERRAT, J.C., VANEL, T., HUROT, J.M., LORRIAUX, C., MAYOR, B., CHAZOT, C., Nephrol. Dial. Transplant., 24, nr. 9, 2009, p. 2792

37.QUNIBI, W.Y., HENRICH, W.L., UpToDate, 2018, https://www. uptodate.com

38. ISAKOVA, T., XIE, H., YANG, W., XIE, D., ANDERSON, A.H., SCIALLA, J., WAHL, P., GUTIERREZ, O.M., STEIGERWALT, S., HE, J. SCHWARTZ, S., LO, J., OJ O, A., SONDHEIMER, J., HSU, C.Y., LASH, J., LEONARD, M., KUSEK, J.W., FELDMAN, H.I., WOLF, M., CHRONIC RENAL INSUFFICIENCY COHORT (CRIC) STUDY GROUP, JAMA, 305, nr. 23, 2011, p. 2432

39. ÄRNLOV, J., CARLSSON, A.C., SUNDSTROM, J., INGELSSON, E., LARSSON, A., LIND, L., LARSSON, T.E., Kidney Int., 83, nr. 1, 2013, p. 160

40.SEILER, S., REICHART, B., ROTH, D., SEIBERT, E., FLISER, D., HEINE, G.H., Nephrol. Dial. Transplant., 25, nr. 12, 2010, p. 3983
41.TANAKA, S., FUJITA, S., KIZAWA, S., MORITA, H., ISHIZAKA, N., PLoS One, 11, nr. 7, 2016, p. e0156860

42.SHIBATA, K., FUJ ITA, S., MORITA, H., OKAMOTO, Y., SOHMIYA, K., HOSHIGA, M., ISHIZAKA, N., PLoS One, 8, nr. 9, 2013, p. e73184

43.SEILER, S., CREMERS, B., REBLING, N.M., HORNOF, F., JEKEN, J., KERSTING, S., STEIMLE, C., EGE, P., FEHRENZ, M., ROGACEV, K.S., SCHELLER, B., BÖHM, M., FLISER, D., HEINE, G.H., Eur. Heart J., 32, nr. 21, 2011, p. 2688

44.BRANDENBURG, V.M., KLEBER, M.E., VERVLOET, M.G., TOMASCHITZ, A., PILZ, S., STOJAKOVIC, T., DELGADO, G., GRAMMER, T.B., MARX, N., MÄRZ, W., SCHARNAGL, H., Atherosclerosis, 237, nr. 1,2014, p. 53

45.SCIALLA, J.J ., W OLF, M., Nat. Rev. Nephrol., 10, nr. 5, 2014, p. 268 46.TAYLOR, E.N., RIMM, E.B., STAMPFER, M.J., CURHAN, G.C., Am. Heart. J., 161, nr. 5, 2011, p. 956

47.IX, J.H., KATZ, R., KESTENBAUM, B.R., DE BOER, I.H., CHONCHOL, M., MUKAMAL, K.J ., RIFKIN, D., SISCOVICK, D.S., SARNAK, M.J ., SHLIPAK, M.G., J. Am. Coll. Cardiol., 60, nr. 3, 2012, p. 200

48.ANDERSEN, I.A., HUNTLEY, B.K., SANDBERG, S.S., HEUBLEIN, D.M., BURNETT, J.C. JR., Nephrol. Dial. Transplant., 31, nr. 5, 2016, p. 767 49.ANDRUKHOVA, O., SLAVIC, S., SMORODCHENKO, A., ZEITZ, U., SHALHOUB, V., LANSKE, B., POHL, E.E., ERBEN, R.G., EMBO Mol. Med., 6, nr. 6, 2014, p. 744

50.ANDRUKHOVA, O., SMORODCHENKO, A., EGERBACHER, M., STREICHER, C., ZEITZ, U., GOETZ, R., SHALHOUB, V., MOHAMMADI, M., POHL, E.E., LANSKE, B., ERBEN, R.G., EMBO J., 33, nr. 3, 2014, p. 229

51.GRABNER, A., AMARAL, A.P., SCHRAMM, K., SINGH, S., SLOAN, A., YANUCIL, C., LI, J., SHEHADEH, L.A., HARE, J.M., DAVID, V., MARTIN, A., FORNONI, A., DI MARCO, G.S., KENTRUP, D., REUTER, S., MAYER, A.B., PAVENSTÄDT, H., STYPMANN, J., KUHN, C., HILLE, S., FREY, N., LEIFHEIT-NESTLER, M., RICHTER, B., HAFFNER, D., ABRAHAM, R., BANGE, J., SPERL, B., ULLRICH, A., BRAND, M., WOLF, M., FAUL, C., Cell. Metab., 22, nr. 6, 2015, p. 1020

52.LEIFHEIT-NESTLER, M., GROßE SIEMER, R., FLASBART, K., RICHTER, B., KIRCHHOFF, F., ZIEGLER, W.H., KLINTSCHAR, M., BECKER, J.U., ERBERSDOBLER, A., AUFRICHT, C., SEEMAN, T., FISCHER, D.C., FAUL, C., HAFFNER, D., Nephrol. Dial. Transplant., 31, nr. 7, 2016, p. 1088

53.SIX, I., OKAZAKI, H., GROSS, P., CAGNARD, J., BOUDOT, C., MAIZEL, J., DRUEKE, T.B., MASSY, Z.A., PLoS One, 9, nr. 4, 2014, p. e93423 54.HU, M.C., SHI, M., GILLINGS, N., FLORES, B., TAKAHASHI, M., KURO0, M., MOE, O.W., Kidney Int., 91, nr. 5, 2017, p. 1104

55.J ONO, S., MCKEE, M.D., MURRY, C.E., SHIOI, A., NISHIZAWA, Y., MORI, K., MORII, H., GIACHELLI, C.M., Circ. Res., 87, nr. 7, 2000, p. E10

56.RAZZAQUE, M.S., ST-ARNAUD, R., TAGUCHI, T., LANSKE, B., Nephrol. Dial. Transplant., 20, nr. 10, 2005, p. 2032

57.EL-ABBADI, M.M., PAI, A.S., LEAF, E.M., YANG, H.Y., BARTLEY, B.A., QUAN, K.K., INGALLS, C.M., LIAO, H.W., GIACHELLI, C.M., Kidney. Int., 75, nr. 12, 2009, p. 1297

58.MIRZA, M.A., HANSEN, T., J OHANSSON, L., AHLSTROM, H., LARSSON, A., LIND, L., LARSSON, T.E., Nephrol. Dial. Transplant., 24, nr. 10, 2009, p. 3125

59.URAKAWA, I., YAMAZAKI, Y., SHIMADA, T., IIJIMA, K., HASEGAWA, H., OKAWA, K., FUJ ITA, T., FUKUMOTO, S., YAMASHITA, T., Nature, 444, nr. 7120, 2006, p. 770

60.KURO-O, M., MATSUMURA, Y., AIZAWA, H., KAWAGUCHI, H., SUGA, T., UTSUGI, T., OHYAMA, Y., KURABAYASHI, M., KANAME, T., KUME, E., IWASAKI, H., IIDA, A., SHIRAKI-IIDA, T., NISHIKAWA, S., NAGAI, R., NABESHIMA, Y.I., Nature, 390, nr. 6655, 1997, p. 45

61.CHRISTOV, M., Curr. Opin. Nephrol. Hypertens., 23, nr. 4, 2014, p. 340

Manuscript received: 16.11 .2018 